\title{
STUDI ETNOZOOLOGI DI SUB DAS MENDALAM SEKITAR KAWASAN TAMAN NASIONAL BETUNG KERIHUN KAPUAS HULU
}

\author{
(Ethnozoology study in Mendalam sub-watershed around the national park of Betung Kerihun \\ Kapuas Hulu)
}

\author{
Angela Angreani, Hari Prayogo, Hafiz Ardian \\ Fakultas Kehutanan Universitas Tanjungpura Pontianak Jl. Daya Nasional Pontianak 78124 \\ Email: angelaangreani189@gmail.com
}

\begin{abstract}
Local communities around Betung Kerihun National Park, especially people who live around the Mendalam River, still use forest resources. One of them is fauna. One of the ethnic communities in the Mendalam River in a Datah Diaan village is Dayak Kayaan and Dayak Punan Bukat. Utilization and use of these animals by the local community has become a tradition for the generations. The people who live around the Mendalam River use a lot of wild animals around them because their residence is surrounded by forests which are still good or protected. This research aims to collect the data of types of animals, which are used by indigenous people in the Mendalam River in their daily lives. This research was conducted by using survey method and the respondents were taken by using snowball sampling. The results showed that there were 85 species of animals that were used by Dayak Kayaan and Dayak Punan Bukat community. Based on grade level, there were 8 classes of animals used, namely Mammals, Amphibians, Aves, Molluscs, Pisces, Reptiles, Insects and Crustaceans, and the most used animals were from the pisces class which consists of 26 types and at least 1 amphibian was used. These animals were used for various needs such as for consumption, treatment, supernatural or mystical, omens, artistic value, and others. The most used animal was for consumption as much as 50\%, for treatment was $25 \%$, for ritual or mystical or omens was $15 \%$, for art was 5\%, and the use of animals for other was $5 \%$.
\end{abstract}

Keywords: Dayak Kayan, Dayak Punan Bukat, Ethnozoology

\section{PENDAHULUAN}

Masyarakat lokal memiliki pengetahuan yang berbeda dalam penggunaan dan pengelolaan sumber daya alam sesuai dengan adat dan budayanya. Pengetahuan lokal merupakan kekayaan budaya yang perlu digali agar pengetahuan tersebut tidak hilang, sebagai data dasar untuk pengembangan sumber daya alam yang lebih bermanfaat dan berdaya guna.Suku Dayak yang berada di Kapuas Hulu diantaranya adalah suku Dayak Kayaan dan Dayak Bukat yang berada di Desa Datah Dian, Putussibau Utara. Masyarakat yang berada di Desa Datah Dian merupakan mayoritas Suku Dayak yang masih bergantung pada hasil alam di sekitarnya. Masyarakat di Desa Datah Dian memiliki pengetahuan lokal dalam memanfaatkan hewan yang ada di sekitar hutan, diantaranya untuk konsumsi, pengobatan, ritual adat dan untuk kesenian. Pemanfaatan maupun penggunaan hewan tersebut oleh masyarakat setempat sudah menjadi tradisi secara turun-temurun. Masyarakat yang tinggal di sekitaran 
sungai Mendalam banyak memanfaatkan satwa liar yang ada di sekitaran mereka karena tempat tinggal mereka dikelilingi hutan yang masih baik/ terjaga. Satwa yang sering dimanfaatkan adalah dari kelas mamalia dan pisces karena mudah didapatkan, suku Dayak yang mendiami sekitar sungai Mendalam adalah Dayak Kayan dan Dayak Bukat jarak tempat tinggal kedua suku ini sangat berjauhan yang ditempuh dengan transportasi jalur air. Untuk Dayak Kayaan karena sudah lebih maju mereka sudah tidak terlalu bergantung dengan hutan disekitarnya dan hanya memanfaatkan seperlunya saja, sedangkan Dayak Bukat masih sangat bergantung dengan sekitarnya karena tempat tinggal mereka yang jauh lebih ke hulu sungai kapuas lebih sering memanfaatkan satwa di sekitarnya.

Untuk memenuhi kebutuhan protein hewani masyarakat di kedua Dusun ini adalah dengan beternak satwa seperti babi, ayam, dan ikan, selain beternak mereka juga pergi ke hutan untuk berburu. Satwa yang paling banyak dimanfaatkan dalam keseharian mereka adalah ikan selain mudah didapat ikan juga masih tersedia banyak disungai karena tempat tinggal mereka di tepi sungai Mendalam. Pemanfaatan satwa untuk obat-obatan berdasarkan kebiasaan dari masyarakat adat pada dua Dusun yaitu Pagung dan Nanga Hovat, saat ini masyarakat sudah jarang menggunakan satwa sebagai obat karena sudah mulai langka dan kebanyakan orang saat ini jika sakit sudah berobat ke rumah sakit atau puskesmas terdekat. Sarana ritual kebudayaan memanfaatkan hewan yang memang sudah sering digunakan sejak orang-orang terdahulu mereka. Ragam pemanfaatan satwa merupakan implikasi dan beragamnya etnis, baik dalam hal jenis satwa yang dimanfaatkan, bentuk pemanfaatan maupun cara memanfaatkannya. Pemanfaatan satwa di Sub DAS Mendalam Kawasan TNBK oleh masyarakat tradisional sudah menjadi tradisi secara turun-temurun. Oleh sebab itu perlu adanya dokumentasi secara tertulis agar pengetahuan tersebut tidak hilang. Penelitian bertujuan untuk mendata jenis-jenis satwa, yang dimanfaatkan oleh masyarakat adat di DAS Mendalam dalam kehidupan sehari hari.

\section{METODE PENELITIAN}

Penelitian dilaksanakan di Desa Datah Dian dengan dua lokasi penelitian yaitu Dusun Pagung dan Nanga Hovat Kecamatan Putussibau Utara Kapuas Hulu. Pengambilan data dilakukan selama \pm 1 bulan dilapangan yaitu dari tanggal 21 Juli - 15 Agustus 2019. Metode penelitian yang digunakan adalah survey dengan teknik pengambilan responden menggunakan snowball sampling atau dilakukan secara berantai dengan meminta informasi pada orang yang telah diwawancarai sebelumnya demikian seterusnya (Poerwandari, 1998) pengumpulan data dengan wawancara dilengkapi dengan kuisioner. Peneliti tidak membatasi jumlah responden maupun objek penelitian, pengambilan 
data akan dihentikan apabila peneliti telah merasa data yang terkumpul sudah jenuh (tidak ada penambahan data lagi).

\section{HASIL DAN PEMBAHASAN}

\section{Jenis satwa yang dimanfaatkan}

Satwa dimanfaatkan masyarakat untuk memenuhi kebutuhan bahan pangan, ritual dan hajatan, komoditas perdagangan, bahan dan media perantara dalam kesenian dan hiburan, untuk kegiatan pertanian, sebagai bahan obat-obatan, dan mitos. Jumlah satwa yang digunakan untuk obat, pangan, dan mitos lebih banyak dibandingkan untuk ritual dan hajatan, sebagai komoditas perdagangan, media kesenian dan hiburan, ataupun kegiatan pertanian. Jenis satwa untuk ritual dan hajatan sebelumnya sudah ditetapkan oleh adat, sementara jenis satwa untuk komoditas perdagangan, media kesenian dan hiburan, serta kegiatan pertanian cenderung karena kebiasaan tradisi dikalangan masyarakat kesepuhan.

Hasil penelitian menunjukan ada 85 jenis satwa yang dimanfaatkan oleh masyarakat Dayak Kayaan dan Dayak Punan Bukat, berdasarkan tingkat kelas diperoleh 8 kelas satwa yang

\section{Pemanfaatan satwa untuk konsumsi}

Pemanfaatan satwa terbagi menjadi dua jenis yaitu pemanfaatan langsung adalah pemanfaatan yang dilakukan tanpa adanya pengolahan lebih lanjut, artinya satwa tersebut langsung dimanfaatkan. Untuk pemanfaatan tidak langsung adalah satwa yang dimanfaatkan perlu dilakukan proses pengolahan terlebih dahulu seperti dimanfaatkan yaitu mamalia, amfibi, Aves, molusca, pisces, reptil, insecta dan crustasea, dan yang paling banyak dimanfaatkan adalah dari kelas pisces yang terdiri atas 26 jenis dan paling sedikit dimanfaatkan dari kelas amfibi sebanyak 1 jenis. Beragam pemanfaatan satwa tersebut mulai dari konsumsi, pengobatan, supranatural $/ \mathrm{mistis,}$ pertanda, nilai seni, dan pemanfaatan hewan untuk lainnya. Pemanfaatan terbanyak untuk konsumsi sebanyak $50 \%$, pengobatan 25\%, ritual/mistis/pertanda $15 \%$, kesenian $5 \%$, dan pemanfaatan hewan untuk lainnya $5 \%$.

Pada kedua dusun yang di teliti pemanfaatan satwa oleh masyarakat setempat yang paling banyak digunakan adalah dari satwa mamalia dan pisces, karena untuk mendapatkannya tidak memerlukan waktu yang lama. Untuk pisces sendiri lebih mudah didapat dan sering dikonsumsi masyarakat pada Dayak kayaan dan Punan Bukat karena tempat tinggal mereka yang berada dekat sungai Mendalam. Secara lengkap jenis satwa yang dimanfaatkan disajikan pada tabel 1 (terlampir).

pemanfaatan untuk konsumsi dan pengobatan. Bagian satwa yang dikonsumsi adalah daging, konsumsi satwa yang diternak lebih diperuntukan untuk hidangan ritual tetapi pada saat tertentu juga menggunakan satwa liar.

Paling banyak dimanfaatkan dalam keseharian mereka adalah ikan selain mudah didapat ikan juga masih tersedia banyak disungai karena tempat tinggal mereka di tepi sungai Mendalam dan 
untuk mendapatkan ikan juga tidak memerlukan waktu yang lama mereka menangkap ikan di sungai dengan cara dijala, pasang pukat atau memancing. Sungai Mendalam masih menyediakan kelimpahan ikan untuk dikonsumsi karena penangkapan selama ini yang dilakukan adalah ramah lingkungan. Untuk memenuhi konsumsi tidak hanya dengan menangkap ikan ada juga yang melakukan perburuan, mereka memilih berburu pada saat musim buah karena pada saat itu satwa yang mencari makan memiliki tubuh gemuk.

Satwa yang paling banyak dimanfaatkan adalah dari jenis ikan dan mamalia yang merupakan satwa liar, untuk ikan karena dekat dengan sungai jadi sangat mudah untuk didapat sedangkan untuk mamalia perlu melakukan perburuan terlebih dahulu. Bagian tubuh satwa yang dikonsumsi sebagian besar adalah dagingnya, cara pengolahannya beragam ada yang dimasak kuah, dan digoreng.

Maksud dari dimasak kuah adalah masakan daging yang diberi air disesuaikan dengan banyak atau sedikitnya daging yang dimasak, sedangkan yang digoreng adalah masakan yang hanya digoreng dengan minyak goreng. Untuk pengolahan lainnya ada juga yang dijadikan sebagai ikan asin dan disalai, jika ikan hasil tangkapannya banyak sebagian ada yang dikonsumsi untuk sendiri dan ada juga yang dijual, selain ikan yang sudah diolah biasanya ada juga yang menjual ikan yang masih belum diolah atau mentah. Cara pengolahan yang paling banyak dilakukan adalah dengan cara dimasak kuah dan digoreng.

\section{Pemanfaatan satwa untuk obat}

Pemanfaatan satwa oleh masyarakat adat Dayak Kayaan dan Bukat tidak hanya sebagai bahan pangan, tetapi juga dimanfaatkan untuk bahan pengobatan. Beberapa jenis penyakit yang dapat disembuhkan seperti tipus, asma, sakit mata, patah tulang dan lain-lainnya. Pemanfaatan satwa tersebut berdasarkan kebiasaan dari masyarakat adat pada dua Dusun yaitu Pagung dan Nanga Hovat, baik dari penggunaannya maupun cara pengolahan tidak semua satwa yang digunakan di Dayak Kayaan juga digunakan oleh Dayak Bukat. Sedikitnya ada 19 jenis satwa yang digunakan sebagai obat oleh kedua suku ada 17 jenis satwa digunakan oleh masyarakat Dayak Kayan sedangkan masyarakat Dayak Bukat hanya 4 jenis yang digunakan sebagai obat beberapa satwa yang digunakan sebagai obat diantaranya sebagai berikut.

Seluruh tubuh dari kelelawar (Megachiroptera) digunakan masyarakat untuk menyembuhkan penyakit asma, cara pengolahannya yaitu dengan membersihkan hawaat dari kotorannya dan rambut halus yang ada di tubuhnya kemudian merebus dan sedikit menambah garam dapur. Hal ini didukung oleh penelitian Ransasaleh (2013) kelelawar jenis $N$. cephalotes dan $P$. alceto mengandung senyawa steroid kelompok astron dan androstan, dan alkaloid dengan kerangka pridinpiridin dan imidazol. 
Mengkonsumsi daging tupai digunakan untuk mengobati diabetes melitus dan menetralisir gula darah. Penelitian ini didukung oleh Dewin dkk., (2017) masyarakat Dayak Seberuang percaya bahwa daging tupai memiliki khasiat untuk penambah stamina dan dipercaya mampu membantu proses penyembuhan bagi penderita diabetes. Burung tekukur satwa dari kelas aves ini digunakan oleh masyarakat untuk mengobati penyakit asma, dimana cara pengolahannya yaitu dibersihkan terlebih dahulu. Bagian yang digunakan adalah empedunya yang direbus dalam air hangat.

Masyarakat menggunakan burung bubut sebagai obat tradisional yang sangat ampuh untuk mengobati patah tulang, Menurut masyarakat untuk dapat menjadikannya obat perlu dipatahkan terlebih dahulu bagian kakinya, kemudian dibacakan sedikit mantra yang tidak sembarangan, kemudian ditunggu sampai beberapa hari jika kaki burung yang dipatahkan bersambung kembali maka akan dipatahkan lagi sampai tidak bersambung. Bekicot dijadikan sebagai obat luka agar cepat kering dengan menggunakan lendirnya. Bekicot selain utnuk konsumsi juga digunakan sebagai salah satu satwa yang berkhasiat obat seperti asma, batuk dan demam. Cara pengolahannya cukup ditumis bagian kepalanya dan dimakan, selian sebagai obat juga sebagai penambah lauk pauk pengganti daging. Masyarakat lebih memilih bekicot untuk pengobatan asma karena lebih mudah didapatkan (Rusmiati $d k k$., 2018).
Ular kobra (Naja naja) darah dari ular kobra digunakan untuk obat gatal, cara penggunaannya sebagai obat yaitu dengan mengoleskan langsung darahnya pada bagian kulit yang gatal. Ikan gabus (Channa striata) digunakan sebagai obat untuk pemulihan setelah operasi, bagian yang digunakan seluruh bagian tubuhnya. Cara pengolahannya hanya cukup dimasak kuah dan direbus. Menurut Ulandari $d k k$ (2011), ikan gabus memiliki manfaat antaralain meningkatkan kadar albumin dan daya tahan tubuh, mempercepat proses penyembuhan pasca-operasi dan mempercepat penyembuhan luka dalam atau luka luar. Trenggiling (Manis javanica) memanfaatkan empedu trenggiling untuk dijadikan obat, empedu trenggiling dipercaya berkhasiat untuk menyembuhkan sakit cukup dengan disalai dan dijemur kemudian merendam empedu yang sudah dikeringkan kedalam air hangat dan langsung diminum.

Ulat bulu digunakan untuk obat gatal yang disebabkan oleh ulat bulu tersebut, pengaplikasiannya dengan mematikan ulat bulunya kemudian diambil kotorannya dan digosokkan di bagian kulit yang gatal. Ular sawah selain dagingnya digunakan untuk konsumsi, lemak ular sawah juga dimanfaatkan masyarakat untuk obat untuk terkena air panas dan melepuh serta obat untuk gatal-gatal. lemak digoreng sampai membentuk minyak, Lemak tersebut dioleskan langsung pada daerah yang terluka dan gatalgatal. Hal ini tidak jauh berbeda dengan 
penelitian Pilatus $d k k$., (2017) pada suku Dayak Kanayant tulang ular atau dalam bahasa Dayak Kanayant di sebut uwar dimanfaatkan sebagai pengobatan untuk sakit pinggang, dan cara pengolahannya sangat mudah yaitu dengan membakar tulang ular kemudian ditumbuk setelah itu di beri air hangat dan penggunaannya diminum.

Daging tokek dijadikan sebagai obat gatal, cara pengolahannya dengan membersihkan terlebih dahulu tokek dari kotorannya setelah bersih dimasak goreng untuk dikonsumsi masyarakat menggunakan tokek sebagai obat gatal. Tidak jauh berbeda dengan penelitian Rusmiati dkk., (2018) pemanfaatan seluruh tubuh tokek rumah untuk mengobati penyakit asma dengan cara pengolahan dibakar kemudian dimakan. Cacing gelang digunakan untuk mengobati sakit tipus, cara pengolahan untuk dijadikan menjadi obat dengan dibersihkan dari kotorannya. tubuh cacing dikeringkan terlebih dahulu kemudian tumbuk sampai halus dan jadi tepung, untuk dikonsumsi sebagai obat tepung dari cacing gelang tersebut dapat di campur pada makanan dan dicampur langsung pada air minum. Didukung oleh penelitian Dewin $d k k$., (2017) masyarakat Dayak Seberuang memanfaatkan cacing tanah sebagai obat tipes.

Air susu dari kucing yang melahirkan dapat dijadikan untuk obat tipus, susu kucing diperas sampai secukupnya. Diberikan kepada orang yang sakit tipus tersebut untuk diminum. Kaki anjing dijadikan obat untuk menaikan trombosit dan demam berdarah, cara pengolahannya dengan membuat sop dari kaki anjing yang dimasak. setelah matang yang dikonsumsi hanya air dari rebusan kaki anjing tersebut. Empedu beruang bermanfaat menyembuhkan sakit setelah terjatuh, pemanfaatan empedu beruang tergolong mujarab dan manjur. agar dapat bertahan lama empedu beruang tersebut di salai sampai kering agar dapat dipakai kembali saat diperlukan, penggunaannya dengan merebus empedu kedalam air hangat kemudian airnya di minum. Maryanto dan Soebekti (2007) masyarakat meyakini empedu beruang madu sebagai obat untuk luka dalam akibat patah tulang, terkilir, dan kecelakaan ringan.

Seluruh bagian tubuh kadal hijau dijadikan untuk obat asma, cara pengolahannya yaitu seluruh badan kadal disalai sampai kering kecuali kotoran perut. Penggunaannya dengan memakan kadal yang telah disalai dan digoreng. Widjaja (2014) mengatakan kadal pohon borneo juga berfungsi sebagai tonik bagi organ paru-paru dan ginjal selain itu ramuan kadal juga mampu meredakan asma dan sebagai obat batuk berlendir. Tupai kecil darah dari tupai kecil ini bermanfaat untuk menyembuhkan sakit mata, dimana setelah didapatkan tupai tersebut langsung di sembelih dan darahnya langsung dioleskan pada daerah sekitar bawah mata orang yang mengalami sakit mata. Masyarakat percaya ini obat 
yang sangat bekerja dengan cepat untuk menyembuhkan sakit mata.

Kepu atau sejenis monyet menurut mitos masyarakat dapat dijadikan obat untuk sakit demam, akan tetapi sangat jarang digunakan karena satwa ini jarang ditemui atau sudah langka Dewin dkk., (2017) masyarakat Dayak Seberuang pernah memanfaatkan monyet merah, masyarakat Desa Gunung Mali tersebut menyebut dengan nama engkelasi. Monyet merah dikonsumsi dagingnya menjadi olahan makanan seperti dibakar atau dipanggang, kandungan protein yang terdapat dalam daging primata ini begitu tinggi sehingga banyak digunakan dalam dunia pengobatan seperti obat untuk masuk angin, dan gangguan perut.

Landak bagian tubuh landak yang dimanfaatkan sebagai obat yaitu bagian hati, khasiat dari hati landak dipercaya dapat jadi penangkal racun. Hati landak langsung dimakan setelah di dapatkan. Penelitian ini didukung oleh Heningsih $d k k$., (2018) yang memanfaatkan usus landak sebagai obat, cara pegolahannya dengan menyimpan usus kecil yang masih terdapat sisa sari-sari makanan di atas perapian atau dijemur agar kering sebagai upaya untuk pengawetan. Pengolahan sebagai obat dengan mengambil usus yang sudah kering kemudian direbus atau direndam air panas, penggunaannya dengan diminum dipercaya dapat menyembuhkan tipes dan malaria. Trenggiling memanfaatkan sisik dari trenggiling untuk dijadikan obat gatal-gatal, sisik trenggiling dibakar terlebih dahulu kemudian ditumbuk sampai halus dan jadi tepung. Tepung dari sisik trenggiling dioleskan pada daerah kulit yang mengalami gatal-gatal.

\section{Pemanfaatan satwa untuk ritual, mistis, dan pertanda}

Menurut kepercayaan masingmasing beberapa satwa dipercayai memberikan pertanda tersendiri bagi masyarakat adat Dayak Kayaan dan Bukat, dimana satwa yang dipercayai dalam memberikan pertanda atas suatau keadaan adalah satwa yang sama. Mereka mempercayai bahwa jika mendengar bunyi atau saat bersamaan satwa tersebut tiba-tiba lewat didepan saat akan berpergian maka tidak diperbolehkan untuk keluar atau pergi yang membawa barang-barang tajam karena akan terjadi sesuatu yang buruk. Untuk saat ini beberapa pertanda dari satwa tersebut sudah jarang atau tidak digunakan lagi. Kijang(Muntiacus muntjak), rusa (Cervus unicolor) Masyarakat mempercayai jika kijang dan rusa sudah memasuki ladang yang baru di persiapkan oleh mereka maka, ladang yang baru digarap tersebut harus ditinggalkan dan tidak boleh dikerjakan lagi. Menurut mereka jika masih mengerjakan ladang yang sudah dilewati oleh rusa dan kijang makan lahan yang dipakai tanahnya sudah tidak bagus lagi.

Burung elang Jika pada saat persiapan lahan untuk ladang tiba-tiba burung ini lewat maka tidak jadi untuk memeriksa lahan untuk ladang baru. Burung elang dipercayai oleh 
masyarakat memberikan suatu pertanda baik dan buruk, untuk melihat apakah jadi pertanda baik atau buruk yaitu sesuai kebiasaan arah yang mereka gunakan. Burung elang tidak hanya memberikan pertanda yang buruk tetapi juga memberikan pertanda yang baik seperti saat kita berpergian tiba-tiba melintas masyarakat mempercayai biasanya akan ada yang bertamu ke rumahnya. Burung bukang Masyarakat mempercayai jika burung ini berbunyi maka akan ada pertanda orang meninggal, biasanya ini menjadi pertanda ada keluarga dekat yang meninggal. Anai-anai biasanya jika sudah ada satwa ini berterbangan didalam rumah akan menandakan air pasang dan banjir.

Tongeret menjadi pertanda untuk ada orang meninggal, biasanya bunyi dari satwa ini yang menjadi pertandanya. Jika suaranya terdengar jauh maka ada keluarga jauh juga yang meninggal sebaliknya jika suaranya terdengar dekat maka jadi pertanda ada keluarga dekat yang meninggal. Manuk tepasi, burung ketupong, burung telajan, dan burung mengulung burung-burung ini dipercaya masyarakat pada zaman dahulu saat pembukaan lahan baru untuk berladang dimana sebelum membuka lahan mereka mencari dimana ada suara-suara burung tersebut maka tanahnya diambil dan dibawa pulang kerumah. Setelah sampai di rumah tanah yang didapat dibagi-bagi, menurut mereka jika mengambil tanah dimana terdengar suara burung itu dan disimpan di lahan yang sudah di siapkan maka akan membuat tanah dan padinya subur serta buahnya bagus.

Ayam selain untuk konsumsi sehari-hari ayam juga digunakan untuk kegiatan acara seperti gawai, yang digunakan biasanya darah, daging, dan satu ekor ayam hidup. Biasanya untuk acara gawai bagain yang digunakan adalah darahnya, dagingnya digunakan untuk konsumsi bersama-sama. Babi selain untuk konsumsi sehari-hari babi juga digunakan untuk acara gawai dimana yang digunakan darah dan dagingnya. Darah babi biasa digunakan untuk acara pengormatan kepada rohroh nenek moyang yang terdahulu sekaligus untuk meminta ijin pada mereka untuk memulai suatu kegiatan. Daging babi digunakan untuk konsumsi bersama-sama pada saat acara gawai.

Untuk saat ini masyarakat Dayak Kayaan dan Bukat sudah jarang menggunakan suara burung pada saat membuka lahan baru untuk berladang, dikarenakan mereka berpikir akan sangat susah untuk membuka lahan baru jika masih mengandalkan suara-suara burung tersebut seperti perlu mengumpulkan tanah-tanah yang dimana suara burung terdengar. Mereka mengatakan jika masih mengikuti kebiasaan orang terdahulu karena selain mencari suara burung dan ada hewan yang tiba-tiba melewati lahan yang sedang dipersiapkan yang harus langsung ditinggalkan akan membutuhkan waktu yang lama untuk mempersiapkan lahan baru. Dari beberapa hewan yang digunakan sebagai pertanda ada yang memiliki 
makna yang berbeda disetiap kepercayaan masyarakatnya walaupun hewan tersebut adalah hewan yang sama.

\section{Pemanfaatan satwa untuk kesenian}

Bermacam bentuk dari kulit, tanduk, dan bulu satwa yang dimanfaatkan sebagai hiasan yang bernilai seni penggunaannya dengan dipajang pada dinding-dinding rumah. Pemanfaatan bagian seperti tanduk, kulit, dan bulu masyarakat Dayak Kayaan dan Bukat Desa Datah Dian Dusun Pagung digunakan sebagai kesenian. Beberapa bagian satwa yang digunakan untuk kesenian diantaranya.

Kulit rusa dimanfaatkan untuk dijadikan bahan dalam pembuatan gendang dikarenakan memiliki suara yang indah dan lembut saat dimainkan dengan alat musik tradisional Dayak Kayaan lainnya pada saat acara-acara gawai yang dilakukan.
Kulit beruang Kulit beruang juga dimanfaatkan sebagai bahan untuk membuat baju adat untuk anak-anak kecil, dan digunakan pada saat ada acara gawai-gawai.

Bulu burung enggang, ruai, dan tajak Selain untuk hiasan dikepala pada saat acara gawai bulu burung enggang juga digunakan sebagai pernak pernik untuk baju adat Dayak Kayaan. Selain bulu kepala burung enggang juga digunakan untuk hiasan topi yang dipakai pada saat acara gawai.

Tanduk rusa Tanduk rusa memiliki nilai seni keindahan sebagai pajangan di dinding, tidak semua rumah warga yang ditemui memiliki hiasan dindingnya tanduk rusa.

Kulit kucing hutan Digunakan oleh masyarakat adat Dayak Bukat untuk baju adat anak laki-laki mereka memakai kulit kucing karena lebih tahan lama dan dapat digunakan berkali-kali. 


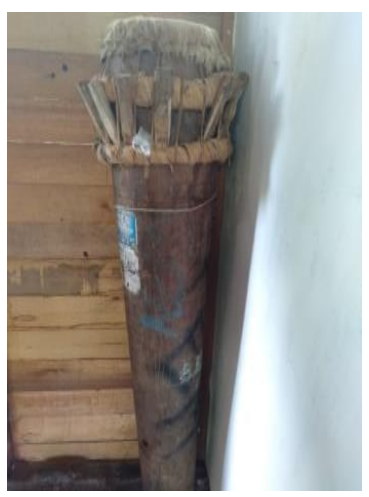

(a)

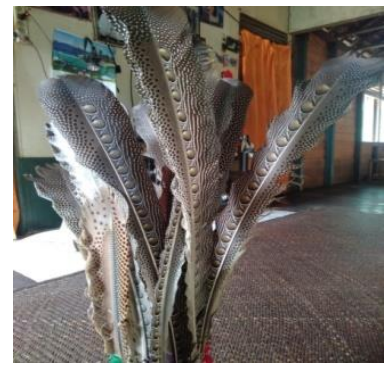

(d)

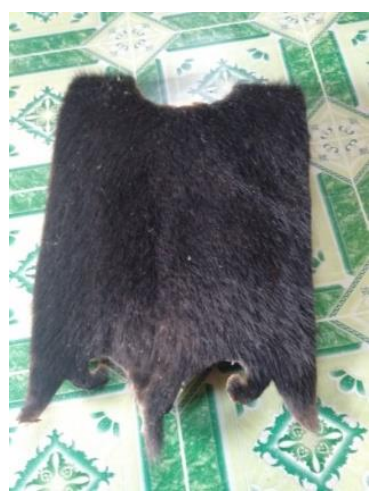

(b)

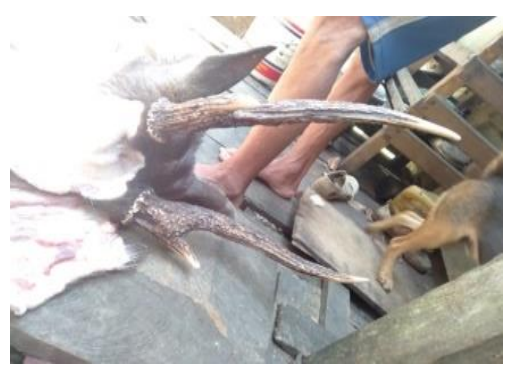

(e)

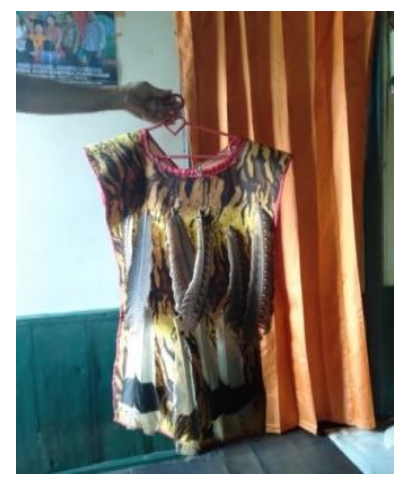

(c)

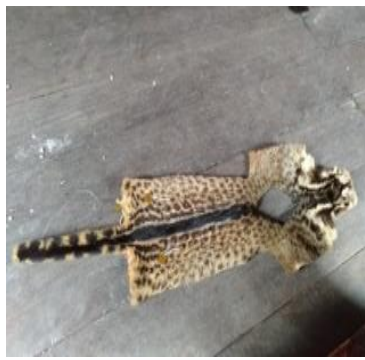

(f)

Gambar 1. (a) kulit rusa yang dijadikan gendang (Deer skin that is used as a drum)

(b) kulit beruang yang dijadikan baju adat untuk anak laki-laki (Bears leather are worn as traditional clothes for boys)

(c) bulu burung enggang yang dijadikan hiasan untuk baju adat (Enggang feathers are used as decoration for traditional clothes)

(d) bulu burung ruai yang dijadikan hiasan untuk baju adat (Ruai feathers are used as decoration for traditional clothes)

(e) tanduk rusa yang dijadikan hiasan dinding rumah (Deer horns used as wall hangings on the house)

(f) kulit kucing hutan sebagai baju adat anak laki-laki (Jungle cat skin as a traditional clothes for boys)

\section{Pemanfaatan satwa untuk lainnya}

Untuk konsumsi,pengobatan, mistis dan pertanda beberapa satwa yang digunakan masyarakat Dayak Kayaan ada yang berpotensi untuk penggunaan lainnya seperti jangkrik dan cacing tanah yang digunakan sebagai umpan pancing dan beberapa jenis burung yang dipelihara akan tetapi tidak semua warga memelihara burung.

\section{KESIMPULAN}

Masyarakat Dayak Kayaan dan Bukat sampai saat ini masih memanfaatkan berbagai jenis satwa yang ada dilingkungan mereka untuk kebutuhan hidup sehari-hari sedikitnya ada 86 jenis satwa yang dimanfaatkan. Bagian satwa yang dimanfaatkan meliputi seluruh badan, daging, empedu, lemak, tulang, tanduk, hati, 
darah, suara, dan cangkang. Daging merupakan yang paling banyak digunakan oleh masyarakat.

\section{SARAN}

Minimnya pengetahuan masyarakat tentang status perlindungan satwa sehingga perlu dilakukan sosialisasi mengenai status konservasi satwa di Desa Datah Diaan Kecamatan Putussibau Utara Kabupaten Kapuas Hulu.

\section{DAFTAR PUSTAKA}

Dewin LV, Anwari MS dan Prayogo H. 2017. Kajian etnozoologi Masyarakat Dayak Seberuang di Desa Gunung Mali Kecamatan Tempunak Kabupaten Sintang. Jurnal Hutan Lestari 5 (4): 978986.

Ilhami, AY. 2015. Etnozoologi masyarakat Adat Kesepuhan Ciptagelar Desa Sirnaresmi Kabupaten Sukabumi Jawa Barat.

Heningsih M, Kartikawati SM dan Anwari MS. 2017. Kajian Etnozoologi untuk Obat-obatan Masyarakat Dayak Belangin di Desa Mu'un Kecamatan Ngabang Kabupaten Landak. Jurnal Hutan Lestari 6(3): 647-653.
Pilatus, Kartikawati SM dan Anwari MS. 2017. Etnozoologi Suku Dayak Kanayant di Desa Babane Kabupaten Bengkayang. Jurnal Hutan Lestari 5 (3): 858-867.

Rusmiati, Anwari MS dan Tavita GE. 2018. Etnozoologi Masyarakat Dayak Bakati di Desa Seluas Kecamatan Seluas Kabupaten Bengkayang. Jurnal Hutan Lestari 6 (3): 594-604.

Ulandari A, Kurniawan D, Putri AS. 2011. Potensi Protein Ikan Gabus dalam Mencegah Kwashiorkor pada Balita di Provinsi Jambi. Fakultas Kedoketraan Universitas Jambi.

Widjaja. 2014. Manfaat Daging Kadal Atasi Asma. (Online). http://detiklife.com/2014/10/16/m anfaat-daging-kadal-atasiasma/diakses pada 15 desember 2019.

Wollenberg, E., A. Uluk., \& M. Sudana. 2001. Ketergantungan Masyarakat Dayak Terhadap Hutan Di Sekitar Taman Nasional Kayan Mentarang. Bogor :CIFOR. 
JURNAL HUTAN LESTARI (2020)

Vol. 8 (2) : 454 - 466

\section{Lampiran}

Tabel 1. Jenis satwa dan pemanfaatannya oleh masyarakat Dayak Kayaan dan Dayak Bukat (Types of animals and their utilization by the Dayak Kayan and Dayak Bukat communities)

\begin{tabular}{|c|c|c|c|c|c|c|c|}
\hline No. & Nama lokal & Nama ilmiah & $\mathbf{K}$ & $\mathbf{O}$ & M/R/P & $\mathbf{K}$ & $\mathbf{L}$ \\
\hline 1 & Kelegook & Achatina fulica & $\sqrt{ }$ & $\sqrt{ }$ & - & - & - \\
\hline 2 & Kelegook mas & Pomacea canaliculata & $\mathrm{v}$ & - & - & - & - \\
\hline 3 & $\mathrm{Si}$ & Helix pomatia & $\sqrt{ }$ & - & - & - & - \\
\hline 4 & Kedukang & Pilsbryoconcha axilis & $\sqrt{ }$ & - & - & - & - \\
\hline 5 & Halang & Ascaris lumbricoides & - & $v$ & - & - & - \\
\hline \multicolumn{8}{|c|}{ Insecta } \\
\hline 6 & Hurap & Trigona $s p$ & $\sqrt{ }$ & - & - & - & - \\
\hline 7 & Anak hinga & Apis dorsata & $\sqrt{ }$ & - & - & - & - \\
\hline 8 & Hiat & Rhynchophorus ferrugineus & $\sqrt{ }$ & - & - & - & - \\
\hline 9 & Hingat & Vespula vulgaris & $\sqrt{ }$ & - & - & - & - \\
\hline 10 & Awah & & $\sqrt{ }$ & - & - & - & - \\
\hline 11 & Ulat bulu & Macrotthylacia rubi & - & 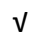 & - & - & - \\
\hline 12 & Tonggeret & & - & - & $\sqrt{ }$ & - & - \\
\hline 13 & Anai-anai & & - & - & $\sqrt{ }$ & - & - \\
\hline 14 & & Phaneroptera falcata & - & - & - & - & - \\
\hline \multicolumn{8}{|c|}{ 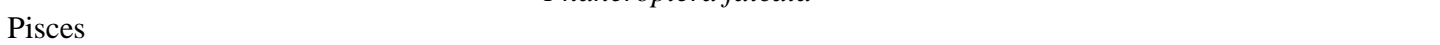 } \\
\hline 15 & Masik bengait & Mystus nemurus & $v$ & - & - & - & - \\
\hline 16 & Masik lewut & Channa striata & $v$ & $v$ & - & - & - \\
\hline 17 & Masik dayo & Channa melasoma & $v$ & - & - & - & - \\
\hline 18 & sejenis ikan toman & Channa lucius & $v$ & - & - & - & - \\
\hline 19 & ikan nila & Oreochromis niloticus & $\sqrt{ }$ & - & - & - & - \\
\hline 20 & Masik putar akar & Clarias nieuhofii & $v$ & - & - & - & - \\
\hline 21 & Masik putar itung & Clarias & $v$ & - & - & - & - \\
\hline 22 & Masik putar jumbo & Clarias gariepsinus & $v$ & - & - & - & - \\
\hline 23 & Masik putar & Clarias bathracus & $v$ & - & - & - & - \\
\hline 24 & Masik halap & Barbodes collingwoodi & $v$ & - & - & - & - \\
\hline 25 & Masik seluang & Rasbora sp & $v$ & - & - & - & - \\
\hline 26 & Masik luki & Luciosoma setigerum & $v$ & - & - & - & - \\
\hline 27 & Ikan kebali & & $v$ & - & - & - & - \\
\hline 28 & ikan langkong & Hampala macrolepidota & $v$ & - & - & - & - \\
\hline 29 & Masik tebela & Tor douronensis & $v$ & - & - & - & - \\
\hline 30 & Masik halap tekalar & Barbonymus schwanenfeldii & $v$ & - & - & - & - \\
\hline 31 & Masik mujuk & Paracrossochilus acerus & $v$ & - & - & - & - \\
\hline 32 & Ajen tange & Tor tambra & $v$ & - & - & - & - \\
\hline 33 & Masik tupai & Gyrinocheilus pustulosus & $v$ & - & - & - & - \\
\hline 34 & Masik helan & Mastacembelus erythrotaenia & $v$ & - & - & - & - \\
\hline 35 & Masik belidak & Notopterus chitala & $v$ & - & - & - & - \\
\hline 36 & Masik kaloh & Osphronemus gouramy & 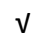 & - & - & - & - \\
\hline 37 & Masik siluk & Sclerophagus fanmousus & $v$ & - & - & - & - \\
\hline 38 & Masik lawang & Pangasius nasutus & $\mathrm{v}$ & - & - & - & - \\
\hline 39 & ikan tapah & Wallago sp & v & - & - & - & - \\
\hline 40 & ikan lais & Cryptopterus limpok & $\mathrm{v}$ & - & - & - & - \\
\hline 41 & Masik kuyur & Basarius yarelli & V & - & - & - & - \\
\hline 42 & Masik belot & Monopterus albus & v & - & - & - & - \\
\hline 43 & ikan buntal & Tetraodon leiurus & v & - & - & - & - \\
\hline \multicolumn{8}{|c|}{ Reptil } \\
\hline 44 & Kelaw & Coura sp & v & - & - & - & - \\
\hline 45 & Biawak & Lanthanotus borneensis & 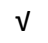 & - & - & - & - \\
\hline 46 & Nyipa' penganen & Phyton breitensteini & v & - & - & - & - \\
\hline 47 & Penganen & Phyton reticulatus & v & - & - & - & - \\
\hline 48 & Kelaw sian & Manouria impressa & & v & - & - & - \\
\hline
\end{tabular}


JURNAL HUTAN LESTARI (2020)

Vol. 8 (2) : 454 - 466

\begin{tabular}{|c|c|c|c|c|c|c|c|}
\hline No. & Nama lokal & Nama ilmiah & $\mathbf{K}$ & $\mathbf{O}$ & $\mathbf{M} / \mathbf{R} / \mathbf{P}$ & $\mathbf{K}$ & $\mathbf{L}$ \\
\hline 49 & Tokek & Gecko monorchus & & $\sqrt{ }$ & - & - & - \\
\hline 50 & Kadal hijau & Dasia olivacea & & $\sqrt{ }$ & - & - & - \\
\hline 51 & Nyipa demu' & Naja naja & & $v$ & - & - & - \\
\hline \multicolumn{8}{|c|}{ Aves } \\
\hline 52 & Manuk pune & Treron sp & $v$ & - & - & - & - \\
\hline 53 & Terkukur & Sreptopelia sinensis & $v$ & $v$ & - & - & - \\
\hline 54 & Puret pergom & Ducula aenea & V & - & - & - & - \\
\hline 55 & Burung puyuh & Turnix suscitator & $v$ & - & - & - & - \\
\hline 56 & Hinyaa & Gallus gallus domesticus & V & - & - & - & - \\
\hline 57 & Burung sempidan & Lophura bulweri & $v$ & - & - & - & - \\
\hline 58 & kareo padi & Amaurornis phoenicurus & 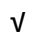 & - & - & - & - \\
\hline 59 & Burung elang & Haliastur indus & - & - & $\sqrt{ }$ & - & - \\
\hline 60 & Burung gagak & Corvus sp & - & - & $\sqrt{ }$ & - & - \\
\hline 61 & & Aethopyga malarensis & - & - & $\sqrt{ }$ & - & - \\
\hline 62 & Burung enggang & Buceros vigil & - & - & - & $v$ & - \\
\hline 63 & Burung ruai & Arguasianus argus & - & - & - & $v$ & - \\
\hline 64 & Burung dangak & & - & - & - & - & \\
\hline 65 & Burung merpati & Columba livia & - & - & - & - & $v$ \\
\hline 66 & & Pycnonotus zeylanicus & - & - & - & - & $\checkmark$ \\
\hline 67 & Burung tiong & Gracula religiosa & - & - & - & - & $v$ \\
\hline \multicolumn{8}{|c|}{ Crustaseae } \\
\hline 68 & Uraang & Macrobrachhium $s p$ & $v$ & - & - & - & - \\
\hline 69 & Tuyo' & Geocarcinus ruricola & $v$ & - & - & - & - \\
\hline \multicolumn{8}{|c|}{ Amfibi } \\
\hline 70 & kodok sawah & Fejervarya cancrivora & $v$ & - & - & - & - \\
\hline \multicolumn{8}{|c|}{ Mamalia } \\
\hline 71 & Telau' & Muntiacus muntjak & $v$ & - & $\sqrt{ }$ & - & - \\
\hline 72 & Payo/rusa & Cervus unicolor & $v$ & - & 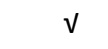 & - & - \\
\hline 73 & Beruk & Macaca nzzemestrina & $v$ & - & - & - & - \\
\hline 74 & Landak & Hystrix brachyura & $v$ & $v$ & - & - & - \\
\hline 75 & Trenggiling & Manis javanica & $v$ & $v$ & - & - & - \\
\hline 76 & Babi hutan & Sus scrofa vittatus & V & - & - & - & - \\
\hline 77 & Uting & Sus barbatus & $v$ & - & - & - & - \\
\hline 78 & Pelanun & Tragulus javanicus & $v$ & - & - & - & - \\
\hline 79 & Teli & Tupaia sp & $\sqrt{ }$ & - & - & - & - \\
\hline 80 & Tupai kecil & Tupaia minor & - & v & - & - & - \\
\hline 81 & Beruang & Helarctos malayanus & - & $v$ & - & - & - \\
\hline 82 & Kucing & Felis domesticus & - & v & - & - & - \\
\hline 83 & Aso' & Canis lupus & - & $v$ & - & - & - \\
\hline 84 & Kelelawar & Megachiroptera & - & V & - & - & - \\
\hline 85 & Kucing hutan & & - & & - & $v$ & - \\
\hline
\end{tabular}

Sumber: Data Penelitian Etnozoologi 2019

Keterangan:

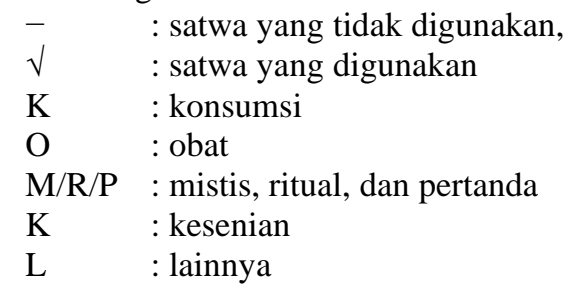

